DOI: $10.30842 /$ ielcp230690152411

Antonio Corso

(Kanellopoulos Foundation / Messenian Society, Athens, Greece)

\title{
CLASSICAL GREEK STATUES MADE BY IMPORTANT MASTERS DESCRIBED IN THE EPIGRAMS OF EVENUS OF PAROS
}

The epigrammist and elegiac poet Evenus is considered in this article. This Parian intellectual lived and worked for most of his life in Athens, where he entered the circle of Socrates and became a friend of Callias and Plato. He must have given a crucial contribution toward the establishment and success of the literary genre of the ekphrastic epigrams, which describe works of art, as it is argued by his epigrams on the Cow of Myron and on Praxiteles' Cnidian Aphrodite. In this very thriving intellectual environment, the unified concept of art, encompassing all visual arts, was conceptually defined.

Keywords: Evenus of Paros, classical Greek visual arts, the Cow of Myron, the Cnidian Aphrodite.

Антонио Корсо

(Kanellopoulos Foundation / Messenian Society, Афины, Греция)

\section{Эпиграммы Эвена Паросского, посвященные статуям знаменитых древнегреческих скульпторов}

В статье рассматриваются свидетельства об Эвене Паросском (ок. 430-ок. 350 г. до н. э.), философе и поэте, который большую часть жизни провел в Афинах, входил в круг Сократа и был дружен с Платоном и Каллием. Автор отождествляет его с Эвеном Грамматиком, автором четырех эпиграмм в «Палатинской Антологии», посвященных скульптурам: две - «Телке» Мирона (А. Р. 9, 717-718) и две «Афродите Книдской» Праксителя (А. Р. 16. 165-166). Внимание Платона к скульптуре (eidolopoiike techne - Plato Soph. 235 b; 236 c) автор предлагает связывать с экфрасисом, а сами эпиграммы Эвена в этом контексте рассматривать как пример этого жанра.

Ключевые слова: Эвен Паросский, древнегреческое классическое изобразительное искусство, экфрастические эпиграммы, скульптура Мирона «Телка», скульптура Праксителя «Афродита Книдская».

The aim of this paper is to focus the distinguished personality of Evenus of Paros ${ }^{1}$ and his original contributions to the interpretations of visual arts and in particular of statues.

He must have been born around $430 \mathrm{BC}$ on Paros.

\footnotetext{
${ }^{1}$ About Evenus, see Bowie 1998: 226-227, with the most important previous bibliography.
} 
That he was a Parian is guaranteed by Hyperides, Kat'Autokleous and Eratosthenes, Peri Chronographion, in Harpocration, s. v. Euenos.

Perhaps the homonymous Evenus who flourished in $456 \mathrm{BC}$ (Hieronymus, Chronicle 111, 12 Helm and Sincellus, Ecloga Chronographica 305 Mosshamer) was his grandfather because both were Parian and elegiac poets.

As other cultivated young men born in poleis subjected to the Delian-Attic League - for example, around 30 years earlier, Agoracritos of Paros ${ }^{2},-$ he felt attracted by the intellectual life of Athens, he settled in this city, entered the circle of Socrates and became a friend of Plato, who had around the same age and wrote about Evenus in his dialogues three times.

In Athens, he opened a school and taught to the famous writer and Syracusan politician Philistus (Suida, s. v. Philistos) ${ }^{3}$.

Socrates praises Evenus in Plato's dialogue Phaedrus 167 a, whose internal date would be around $410 \mathrm{BC}$ :

'Shall we not bring the illustrious Parian, Evenus, into our discussion, who invented covert allusion and indirect praises? And some say that he also wrote indirect censures, composing them in verse as an aid to memory' (transl. Loeb).

This presentation of our poet makes him an important figure in the world of philosophical discussions around Socrates.

Socrates mentions again Evenus in Plato's Apology 20 a-c, of course to be dated in $399 \mathrm{BC}$ :

'There is also another wise man here, a Parian, who I learned was in town. (...) Who has knowledge of that kind of excellence, that of a man and a citizen? (...) 'Evenus', said he (scil.: Callias), 'Socrates, from Paros, five minae. And I called Evenus blessed, if he really had this art and taught so reasonably' '. (transl. Loeb)

We argue from this passage that Evenus by 399 BC had opened his famous school in Athens and that wealthy Callias thought to send his two sons to this school.

Finally, Plato mentions him in his Phaedo, whose internal date of course is also $399 \mathrm{BC}$.

In $60 \mathrm{~d}-61 \mathrm{c}$, Cebes tells Socrates, in prison waiting to drink his hemlock, that 'Evenus asked me the day before yesterday why you who never wrote any poetry before, composed these verses [metrical versions of Aesop's Fables and a Hymn to Apollo] after

\footnotetext{
${ }^{2}$ About Agoracritus, see Despinis 1994.

${ }^{3}$ About Philistus, see Frisone 2008: 143-158.
} 
you came to prison. Now, if you care that I should be able to answer Evenus when he asks me again - and I know he will ask me - tell me what to say.' 'Then tell him, Cebes', said he (scil.: Socrates) the truth, that I composed these verses not because I wished to rival him or his poems, for I knew that would not be easy. (...) So tell Evenus that, Cebes, and bid him farewell, and tell him, if he is wise, to come after me as quickly as he can (...).' And Simmias said, "What a message that is, Socrates, for Evenus! I have met him often, and from what I have seen of him, I should say that he will not take your advice in the least if he can help it. "Why so?" said he (scil.: Socrates). "Is not Evenus a philosopher?" "I think so," said Simmias. "Then Evenus will take my advice (...). Perhaps, however, he will not take his own life, for they say that is not permitted.' (transl. Loeb)

This passage conveys the great fame of Evenus as both poet and philosopher in the early $4^{\text {th }} \mathrm{c}$. BC.

His elegiac poems became famous and are quoted by Aristotle, Nicomachean Ethics 7. 10. 4 and Eudemian Ethics 2. 7. 4.

Evenus was regarded important even in AD $1 \mathrm{c}$,, because Quintilian 1. 10. 17 wrote that 'Archytas and Evenus regarded grammatike as subordinate to music' (transl. Loeb).

His expertise in the field of the grammatike, which he probably taught in his school, leads to the identification of the Parian Evenus with Euenos Grammatikos, author of epigrams found in the Greek Anthology. Attributions of epigrams to Evenus sic et simpliciter should also be given to this Evenus because he was the most famous poet with this name.

Philippus, Greek Anthology 4. 2. 13, who compiled an anthology of epigrams in the Julio-Claudian period, writes that 'you may compare Evenus to a laurel' (transl. Loeb).

Four epigrams by Evenus are ecphrastic of statues.

Two concern the Cow of Myron ${ }^{4}$, which at the time was set up on the upper terrace of the Acropolis of Athens, near the great altar of Athena.

The first of these two poems is Greek Anthology 9.717:

'Either a complete hide of bronze clothes here a real cow, or the bronze has a soul inside it.' (transl. Loeb)

Thus the masterpiece of Myron is praised because it overcomes the mimesis and embodies the psyche of the represented subject.

\footnotetext{
${ }^{4}$ About the Cow of Myron, see Corso 1994: 49-91 and Squire 2010: 589634.
} 
The second epigram is ibidem 718:

'Perhaps Myron himself will say this: "I did not mould this heifer, but I recreated its figure".'

This epigram is also important because it stresses two aspects: the exaltation of the master and the attribution of creative power to him.

The sequence of epigrams celebrating the Cow of Myron in the $9^{\text {th }}$ book of the Greek Anthology is chronological: after epigrams attributed to Anacreon, and probably due to the Athenian Anacreontic circle of the late $5^{\text {th }} \mathrm{c}$. BC, there are these two epigrams of Evenus followed by an epigram of Leonidas of Tarentum: thus the two epigrams of Evenus must be earlier than the early Hellenistic period and must be attributed to our Evenus.

Other two epigrams of Evenus praise the Cnidian Aphrodite of Praxiteles 5 .

The first is Greek Anthology 16. 165:

'Pallas and the wife of the son of Cronos said, when they saw the Cnidia: "We are wrong in finding fault with Paris" .'

The second is ibidem 166:

'The neatherd alone saw of old on the mountains of Ida her who gained the prize of beauty, but Praxiteles has set her in full view of the Cnidians, having the vote of Paris to attest his skill.' (transl. Loeb)

These epigrams again exalt the master, Praxiteles, because he overcame the mimesis and was able to reach and capture the full beauty of the goddess.

Evenus was of the same age of Plato, thus as Plato he may have died when he was old, around $350 \mathrm{BC}$ or even later, and thus may have been alive when Praxiteles conceived the Knidia probably in the years of his peak, in 364-361 BC.

These poems, with many others, also suggest that the Cnidia represented the goddess while she bathed before the judgment of Paris ${ }^{6}$. This bath had been already celebrated by Euripides (Andromache 274-286 and Iphigenia at Aulis 182-184 and 12911308), thus was well inside the mythical culture of Athens in late classical times. Euripides' authority upon Praxiteles had been already noticed in the ancient art criticism (Callistratus 8).

\footnotetext{
${ }^{5}$ About the Cnidian Aphrodite, see Corso 2007: 9-187, with all relevant previous bibliography.

${ }^{5}$ About this issue, Corso 2014 a: 57-64.
} 
These ekphrastic epigrams should be compared to the three ekphrastic epigrams of works of art attributed to Plato, because their contents are very similar. I specify here that both the Palatine Anthology, by Constantine Rhodius, and the Planudean one, by Maximus Planudes, distinct very clearly the epigrams attributed to Plato the philosopher from those attributed to a Plato Minor of AD $1^{\text {st }} \mathrm{c}$. These epigrams are attributed to the philosopher by Planudes, thus their down-dating to Roman times, suggested by Havelock ${ }^{7}$, must be rejected.

The first epigram is ibidem 160:

'Paphian Cythereia came through the waves to Cnidus, wishing to see her own image, and having viewed it from all sides in its shrine in which you can watch around, she cried, "Where did Praxiteles see me naked?" Praxiteles did not look on forbidden things, but the steel carved the Paphian as Ares would have her.'

The second epigram is ibidem 161:

'Neither did Praxiteles nor the chisel work you, but you stand just as of old when you came to the judgment.' (transl. Loeb)

Thus both Plato and Evenus agree on the following concepts: 1 . Praxiteles overcame the mimesis and 2. The Knidia represented the goddess bathing prior to the judgment of Paris.

Finally, Plato, ibidem 210 is also relevant: it describes the sleeping Eros which was also attributed to Praxiteles ${ }^{8}$.

'When we entered the deep-shadowed wood we found within it the son of Cytherea, like unto rosy apples. Nor had he the quiver that holds arrows, nor his bent bow, but they were hanging on the leafy trees, and he lay among the sore-blossoms smiling, bound fast by sleep, and above him the tawny bees were sprinkling on his dainty lips honey dripping from the comb' (transl. Loeb).

This poem celebrates the sleep of Eros as absence of pain in human souls, and that idea is very much in keeping with the Platonic notion of love as suffering.

Thus we must conclude that the ekphrastic epigram of works of art was 'invented' in the Platonic school in order to stress the overcoming of the mimesis by few extremely talented masters. Moreover this genre, since it glorifies the masters but rarely mentions the patrons, is at the beginning of the prevalence of masters upon patrons in the evaluation of works of art of ancient art criticism.

\footnotetext{
${ }^{7}$ See Havelock 1999: 153-155.

${ }^{8}$ See Corso 2014 b: 70-75 and Riccomini 2016: 85-94.
} 
Another important innovation of this school is the notion of 'art' encompassing all visual arts.

This art, which includes painting, sculpture and any other visual art, was called by Plato eidolopoiike techne in Sophista $235 \mathrm{~b}$ and $236 \mathrm{c}$ : 'the art of making images'. This art is divided in two branches: the eikastike techne which makes figures by imitation, and the phantastike, which makes figures by mental imagination.

This Platonic unitary definition of visual arts will be translated to Latin with the notion of videndae artes (Horace, Epistles 2. 1. 242) and will be the basis of the catalogue of the 10 most important artists, including architects, painters and sculptors, in the middle Byzantine period (Tzetzes, Epistles 42, see also Codex Vaticanus Graecus 989, p. 110) ${ }^{9}$.

\section{Works cited}

Barbanera, M. 2016: Review of Arte - Potere, by M. Castiglione and A. Poggio (eds.). Gnomon 88: 230-238.

Bowie, E. 1998: Euenos [1] von Paros. DNP 4: 226-227.

Corso, A. 1994: La vacca di Mirone. NumAntCl 23: 49-91.

Corso, A. 2007: The Art of Praxiteles II. Rome.

Corso, A. 2014: The Art of Praxiteles V. Rome.

Corso, A. 2014 b: The Theme of bathing Aphrodites in classical Greece. Orbis Terrarum 12: 57-64.

Despinis, G. 1994: Agorakritos. EAA Suppl. 2. 1. http://www.treccani.it/ enciclopedia/agorakritos_\%28Enciclopedia-dell\%27-ArteAntica\%29/

Frisone, F. 2008: Dalla solidarieta' alla dynasteia: le esperienze della grecita' occidentale in Antioco e Filisto. In: M. Lombardo (ed.), Forme soprapoleiche e interpoleiche di organizzazione del mondo Greco antico. Lecce: 143-158.

Havelock, C. M. 1999: Review of Sculptors and Sculpture of Caria and the Dodecannese, by I. Jenkins and G. B. Waywell (eds.). AJA 103: $153-155$.

Riccomini, A. M. 2016: Su una statua di Erote dormiente. $R d A$ 40: 85-94.

Squire, M. 2010: Making Myron's Cow Moo. AJPh 131: 589-634.

Tanner, J. 2006: The Invention of Art History in Ancient Greece. Cambridge.

\footnotetext{
${ }^{9}$ For the wrong opinion that this notion of 'art' did not exist in ancient times, see e.g. Tanner 2006: 1-302 and Barbanera 2016: 230-238, particularly 237-238: 'Il concetto di arte (...) si forma nel XVIII secolo'.
} 